\title{
Strategic Approach of Tahfiz Programs for Malaysian Polytechnics
}

\author{
Yusni Mohamad Yusak1, Khadijah Abdul Razak ${ }^{*}$, Mohd. Aderi Che Noh ${ }^{2}$, \\ Sri Andayani Mahdi Yusuf1, Norsaadah Din @ Mohamed Nasirudin ${ }^{3}$ \\ ${ }^{1}$ Fakulti Pendidikan, Universiti Kebangsaan Malaysia (UKM), Selangor, Malaysia \\ ${ }^{2}$ Department of Islamic Education, Sultan Idris Education University (UPSI), Tanjung Malim, Perak, Malaysia \\ ${ }^{3}$ Pusat Pengajian Teras, Kolej Universiti Islam Antarabangsa Selangor (KUIS), Bangi, Selangor, Malaysia \\ Email: ^khadijah.razak@ukm.edu.my
}

How to cite this paper: Yusak, Y. M., Razak, K. A., Noh, M. A. C., Yusuf, S. A. M., \& Nasirudin, N. D. M. (2019). Strategic Approach of Tahfiz Programs for Malaysian Polytechnics. Creative Education, 10, 2711-2717.

https://doi.org/10.4236/ce.2019.1012197

Received: October 16, 2019

Accepted: November 25, 2019

Published: November 28, 2019

Copyright (c) 2019 by author(s) and Scientific Research Publishing Inc. This work is licensed under the Creative Commons Attribution International License (CC BY 4.0).

http://creativecommons.org/licenses/by/4.0/

\begin{abstract}
The implementation of tahfiz programme in polytechnics is aimed towards producing highly marketable graduates and skilled human capital in technical and vocational education (TVE). This programme is developed to integrate worldly and ukhrawi knowledge to produce professional huffaz who are skilled and competent, conforming to the needs of the ummah and the nation. In line with the current global development and demand, the curriculum for polytechnic's tahfiz programme is developed in collaboration with Darul Quran (DQ) to produce dynamic and deductive semi-professional workforce. The combination of the core courses, elective courses and the institution's compulsory courses becomes the essential components for the curriculum. Elements like the programme synopsis, programme overview, delivery methods, assessment methods and referencing, complement the main aspects of the programme proforma. Strategic approach to be considered in order to comply with the standard curriculum demand of tahfiz programme in TVET institutions; small number of students, lack of promotions, and limited number of trained lecturers are among the main challenges that need to be addressed in the future.
\end{abstract}

\section{Keywords}

Strategic Approach, Tahfiz Programme, Malaysian Polytechnic, Technical and Vocational Education Training Institutions, Direction, Challenges

\section{Introduction}

Studying Quran knowledge is the most important thing in the muslim's life. It's coincided with the prophetic traditions of the Prophet Muhammad S.A.W, he 
said "The graters Muslim who's study the contents of Qur'an and to spread it".

Since then, al-Quran has been studied and memorized in the chest of the companions, until today. Modern education of the 21st century also does not miss applying the element of memorization (hifz) as an important element and alternatives to the students. The elements of memorization and preservation of the Quranic Knowledge are applied as early as primary education, to the secondary level and continue to higher education. The memorization in Quranic education known as Tahfiz al-Quran education is offered in all fields and ranks exclusively in technical and vocational fields.

\section{Background}

Tahfiz al-Quran programme in polytechnics is a continuation of the implementation of the tahfiz programme at the secondary level. Shahril and Baba (2013) and Arshad (2015) reported, the tahfiz programme at the secondary level which is known as the Ulul Albab Tahfiz Programme was offered for the first time at the Imtiyaz Yayasan Terengganu Secondary School (SMIYT).

According to Abdullah (2008), Ismail (2012) and Arshad (2015); SMIYT was set up to make Terengganu a major Islamic education hub in Malaysia through the modernization of sekolah pondok. The success of producing huffaz among students who completed Form Five had became the catalyst for the offering of the tahfiz programme by the Federal Territory Islamic Religious Council (MAIWP), the Majlis Amanah Rakyat (MARA) and the Ministry of Education Malaysia (KPM). KPM later introduces Ulul Albab Tahfiz Model (TMUA) and Integrated Tahfiz Curriculum (KBT) for its secondary education.

\section{Problem Statement}

Studying the al-Quran is the most important aspect of every Muslim compared to others sciences. It's in line with the fiqh of "Iqra" the first verse passed on to the Prophet Muhammad S.A.W. There for mastery of the Quranic skills according Din (1992) is directly related to the ability of one to place Islam as a way of life. Polytechnics take on the challenge of offering a tahfiz certification program in addition to offering Diploma programs to students. The effort towards realizing the passion involves the commitment of all stakeholders. This paper is expected to provide a comprehensive overview of the direction and challenges that will be faced, as well as a guide to the management taking the initial steps to address any potential probabilities. In addition, it can also be used as a reference to researchers and the overview of the tahfiz certification program offerings in polytechnics which are still underdeveloped by previous researchers.

\section{Research Methodology}

This study uses library approach and document analysis where researchers study previous researches related to the topic, journals, books, articles, proceedings, theses, paperworks, minutes of meetings and reports. 


\section{Islamic Studies in Polytechnic}

Polytechnic's Islamic Studies (IS) Curriculum is mandatory for Muslim students, in which, the students must pass the course as it is a requirement for graduation. IS in polytechnics emphasizes on developing the three fundamental knowledge in Islam that are aqidah, syariah and akhlak. The basic conception works as the foundation that creates profound understanding and assurance on the concept of tauhid, conducts and students' muamalat (Yusni \& Zainab Hanina, 2013). Continuous assessment is conducted to test the students' knowledge, understanding and how they apply them.

The offering of various tahfiz programmes at the secondary level is not extended to the tertiary level especially at the polytechnics. Yusak \& Samad (2013) reported that the element of memorization in the polytechnic's IS curriculum is only seen in one of the practical assessments in the Islamic Studies curriculum component and specialization. Through the polytechnic's PI curriculum, assessment is carried out with a specific focus on the prayer, perfecting its conduct, and the memorization of short chapters of the Quran.

Saad et al. (2015), Yusof and Karim (2016) proposed that tahfiz education should be extended to a higher level as a continuation of the tahfiz programme offered at the secondary level. This coincides with the Bahagian Pembangunan Dasar (2015), Talib et al. (2017) that the offering of tahfiz programme in polytechnics is to preserve the students' memorization as well as to attract them to continue their studies at the technical, vocational education and training (TVET) institutions.

The proposal is supported by Muhyiddin's, Ramli, \& Azimi (2014) statement that the implementation of Tahfiz Programme (Ulul Albab Tahfiz Model) should not be restricted to school level only but it should be extended to the Higher Learning Institutions (IPT). This is intended to produce knowledgable and steadfast Ulul Albab generation, who masters the technical and vocational education. Saad et al. (2015) added, Muhyiddin's assertion on the above-mentioned tahfiz programme offering became the source of power to offer tahfiz programme in Malaysian Polytechnics.

In conclusion, the offering of the tahfiz programme in polytechnics should be realized as a preservation of the Quranic knowledge and as the means to shelter the huffaz among polytechnic students. However, some fundamental issues need to be refined before the tahfiz programme is offered the process of developing the tahfiz curriculum, the implementation method, the assessment, the admission requirements and the expectations on the obstacles needed to be faced and the solutions.

\section{Lifelong Learning for Islamic Education}

The Lifelong Learning for Islamic Education (PISH) is the continuation of the Lifelong Learning (PSH) that has started in the Ministry of Higher Education's (KPT) Community Colleges since 2000. PISH was elevated as an agenda by the 
former Education Minister in the UMNO General Assembly on 7th December 2013 which proposed PISH to be implemented and made as the country's main policy. Yassin (2013), Hasibuan and Muda (2014) concludes that PISH is a lifelong education towards a better self-improvement in both forms, vertical (hablumminallah) and horizontal (hablumminannas). A well-planned PISH programme is a constant protraction of teaching and learning (T \& L) of Islamic Education to Muslims in Malaysia.

On 5th April 2014, Yusak and Noh (2016) reported, PISH, as a systematic, organized and planned programme, was launched at the Ledang Community College (LJCC), Johor by the Former Deputy Prime Minister. PISH offers religious and spiritual programmes like the Tahfiz al-Quran Programme, Chained-Narrated Book Studies Programme and the Aqidah Strengthening Programme. On top of that, PISH also offers technical skills programmes to match the needs of local communities. All PISH programmes that have been planned and scheduled are advertised and promoted through newspapers, print and electronic media from time to time.

The proposal on starting the Tahfiz Programme in Malaysian Polytechnic, according to Saad et al. (2015) and Talib et al. (2017) is the resolution of the National Seminar on Polytechnic's Islamic Education and Research, 2014 (SKPI'14), JPP, in Behrang, Perak. Saad et al. (2015) added, a steering Committee is set up to study, plan, prepare and present proposal papers for the tahfiz programme at Malaysian Polytechnics. Fifteen sessions comprising meetings, workshops and benchmarking visits between the Steering Committee and stakeholders were held from 2014 to 2017.

Yusak and Noh (2016) reported, the Tahfiz programme in Polytechnics is part of the effort to empower Islamic Studies (IS) and the Lifelong Learning for Islamic Education (PISH) initiated by the former TPM in 2013. The implementing polytechnics' board of management should think of the appropriate methods and approaches that suit the programmes offered for students in the technical, vocational education, and training. This Tahfiz Programme at the polytechnics will not only meet the industry's needs on the semi-skilled and competent workforce in TVET, it will also produce Huffaz Engineers (Eng, $A r, S r, L a r$.) or Ingenieurs (Ir) in Malaysia.

\section{Polytechnic's Tahfiz Programme}

Tahfiz programme in polytechnics, according to Saad et al. (2015) will integrate the Diploma of International Trade's curriculum with the Tahfiz Darul Quran JAKIM's Certification Curriculum. The steering committee suggested that the Tahfiz Programme at polytechnics to be offered to selected group of existing polytechnic students and this will later be introduced to other interested polytechnics from time to time. The need of using DQ's curriculum is to meet the requirements outlined by DQ and to gain their Tahfiz Malaysia Certificate (STM), Jakim's recognition, and to be acknowledged by the Public Service Department 
for the purpose of job appointments in the public sector.

The main objective of the offering of the Tahfiz Programme, according to the steering committee, is to produce graduates with high marketability levels to meet the needs of the industry and the prospective employers. The steering committee added, this ongoing pace is part of the effort to produce human capital and skilled huffaz who masters both worldly and ukhrawi knowledge (Yusak \& Noh, 2016).

\section{Proposal of Tahfiz Programme in Polytechnics}

The Tahfiz programme in Malaysian Polytechnics is implemented using two approaches that are:

1) Tahfiz Certification Programme (Program Pensijilan Tahfiz-PST).

2) Pre-Tahfiz al-Quran al-Karim Programme (Pra-Tahfiz al-Quran al-Karim PTQK).

The Tahfiz Certification Programme (PST) according to the DQ Programme Coordinator is a full-time tahfiz programme that will be implemented simultaneously with the polytechnic's Diploma programme. Students will attend both TVET Diploma programme and Darul Quran Certification Programme, JAKIM concurrently. Students who have successfully completed 30 juzuk will be awarded with Certificate of Tahfiz Malaysia (STM), Darul Quran, JAKIM. STM is a value added certificate which is equivalent to the professional certification from other institutions. The first cohort of students begins in June 2017 at Sultan Salahuddin Abdul Aziz Shah Polytechnic (PSA), Shah Alam, Selangor.

As for the Pre-Tahfiz al-Quran al-Karim Programme (PTQK) as reported by Khasniza and Darni (2016), it is offered on a part-time basis. The programme aims to produce students who love the Quran and lead their daily life as outlined in the Quran and al-Hadith. The pilot programme for this Pre-Tahfiz programme was conducted at Sultan Salahudin Abdul Aziz Shah Polytechnic (PSA), Shah Alam and Sultan Idris Shah Polytechnic (PSIS), Sabak Bernam, in collaboration with Darul Quran (DQ), JAKIM.

This PTQK programme which runs in both polytechnics focuses on promoting PST. The implementation of PTQK according to the PTQK Mudirs, Sharoni bin Ismail (PSA) and Tobroni bin Mohd Sahlan (PSIS) is open for full-time students pursuing a Diploma or Bachelor's Degree programme at the institution. Students with a keen interest in memorizing al-Quran al-Karim are selected to enrol.

The recruitment process, according to PSA's PTQK Coordinator, Abd Halim bin Abd Hadi, involves advertising about the student's recruitment followed by a special interview session. Shortlisted candidates were given 45 minutes to memorize particular verses in the al-Quran al-Karim before the tasmik session. Add Halim, this crucial part is a prerequisite for the students to enrol in the programme. This interview method which was conducted at both institutions is similar with the interview method (muqabalah) implemented in DQ to select 
full-time candidates for its Diploma Tahfiz al-Quran al-Karim programme.

Yusof and Karim (2016) reported; besides memorizing, the students are also required to attend Tajwid and Maharat Quran (Quranic Skills) classes every Saturday. These classes are intended to correct the students' articulation (mahraj), to ensure the usage of correct vowel length in Quran reading as well as to provide extra knowledge of the Quran.

Tasmik and tahriri classes are also conducted to further enhance the students' memorization. The classes are held every night from Monday to Friday, Tajwid and Maharat al-Quran classes are conducted every Saturday, from 08.00 a.m. to 01.00 p.m. at the polytechnic's Islamic Centre. Khasniza and Darni (2016) added, two al-Quran teachers will review the students' readings every night from $08.00 \mathrm{pm}$ to $09.30 \mathrm{pm}$. These students will be provided with accommodation, food and clothing, and lunch for Saturday's sessions. Certificate of participation is awarded to students who have successfully completed at least 3 juzuks at the end of PTQK.

\section{Conclusion}

Tahfiz Programme in Polytechnics is a new programme offered to support the government's initiative to strengthen the implementation of Islamic Education and to instigate the Lifelong Learning for Islamic Education in Malaysian Polytechnics. The offer of this programme is generally to create holistic human capital, employing two fields of knowledge namely worldly and ukhrawi knowledge. The offering of PST and PTQK programme to full-time students at Malaysian Polytechnics is focused on producing Huffaz Engineers (Eng, Ar, Sr. Lar) and Huffaz Ingenieurs ( $I r$ ) to join the country's professional and semi-professional work-force. In specific, the execution of PTQK is seen to be a stimulus in promoting Tahfiz Education in Malaysian Polytechnics. It will also attract the huffaz to pursue their studies in the field of technical, vocational education and training (TVET) in the polytechnics.

\section{Acknowledgements}

This researcher would like to acknowledge the Ministry of Higher Education (MoHE) for the financial funding of this research through Research Grant GG-2019-058 and PP-FPEND-2019.

\section{Conflicts of Interest}

The authors declare no conflicts of interest regarding the publication of this paper.

\section{References}

Abdullah, A. H. (2008). Program Ulul Albab: Satu Dimensi Baru Dalam Pengembangan Pendidikan Islam Di Negeri Terengganu. In M. Zamri, N. Y. Nik Mohd Rahimi, T. Ab. Halim, B. Harun, \& A. Azhar (Eds.), Prosiding Wacana Pendidikan Islam Peringkat 
Kebangsaan Siri Ke-6. Kuching: Biro Perkhidmatan Pendidikan, Majlis Islam Sarawak, JPS. (In Malay)

Arshad, M. A. (2015). Program Ulul Albab Dalam Sistem Pendidikan Di Malaysia. Jurnal Kurikulum \& Pengajaran Asia Pasifik, 3, 22-35. (In Malay)

Bahagian Pembangunan Dasar, J. (2015). Pelaksanaan Program Laluan Khas Lepasan Sekolah Tahfiz Ke Politeknik. Putrajaya. (In Malay)

Din, H. (1992). Tasawwur Islam. Shah Alam: Hizbi Sdn. Bhd. (In Malay)

Hasibuan, M. F., \& Muda, W. (2014). Pendidikan Seumur Hidup Dalam Perspektif Pendidikan Islam. In Artikel Ilmiah (pp. 1-6). (In Malay)

Ismail, N. M. (2012). Program Ulul Albab Suatu Proses Tranformasi Pendidikan Malaysia: Kajian Kes Sekolah Menengah Imtiaz, Terengganu. In Workshop Antarabangsa Pembangunan Berteraskan Islam $V$ (pp. 1-11). Medan: Universitas Muhammadiyah Sumatera (UMSU). (In Malay)

Saad, A. M., Zuhair, A. R., Abu Zarrin, S., Nor Hayati Fatmi, T., Yusni, M. Y., \& Zainab Hanina, A. S. (2015). Kertas Cadangan Pelaksanaan Program Tahfiz Model Ulul Albab Di Politeknik, Jabatan Pengajian Politeknik, Kementerian Pendidikan Malaysia. Putrajaya. (In Malay)

Safina, R., \& Mohd Rafie, A. (2014). Tahfiz Model Ulul Albab mungkin diperluas ke IPT-Muhyiddin. Utusan Publication, 2016. (In Malay)

Shahril, A. R., \& Baba, S. (2013). Integrating Ulul Albab Education and Science Education in Development Insan Ta'dibi Generation: A Case Study of Mara Junior Science College (MJSC). In WEI International Academic Conference Proceedings (pp. 96-103). Antalya: The West East Institute.

http://www.westeastinstitute.com/wp-content/uploads/2013/02/Z-ANT13-236-Mohd-S hahril-Bin-Ahmad-Razimi.pdf

Talib, N. H. F., Bani Hidayat, M. S., \& Ab. Halim, T. (2017). Program Pengajian Tahfiz dan Asas Penawarannya di Politeknik: Satu Sorotan. Tinta Artikulasi Membina Ummah, 3, 1-13. (In Malay)

Yassin, M. (2013). Menyambung Risalah Perjuangan Suci. Majlis Perasmian Perhimpunan Pergerakan Wanita, Pemuda Dan Puteri UMNO 2013 (pp. 1-17). (In Malay) http://www.penaminang.com/2013/12/teks-ucapan-timbalan-presiden-umno.html

Yusak, M. Y., \& Noh, M. A. C. (2016). Halatuju Program Tahfiz di Politeknik Malaysia. In Wacana Pandidikan Islam Siri 11 2016. Bangi: Universiti Kebangsaan Malaysia. (In Malay)

Yusak, M. Y., \& Samad, Z. H. A. (2013). Halatuju Kurikulum Pendidikan Islam Di Politeknik Malaysia Satu Tinjauan Awal. In 2nd International Seminar on Quality and Affordable Education (ISQAE 2013) (pp. 166-172). Skudai: Universiti Teknologi Malaysia. (In Malay)

Yusof, D. M., \& Karim, A. K. (2016). Pra-Tahfiz Al-Quran Al-Karim. Shah Alam. (In Malay) 